\title{
Mirosław MOROZ
}

\section{Wybrane aspekty zastosowania Internetu w polskich małych i srednich firmach}

\section{Wstęp}

W ostatnich latach dochodzi do dynamicznego zwiększania zasięgu zastosowania technologii teleinformatycznych w przedsiębiorstwach. Trend ten nie omija również małych i średnich firm działających w Polsce. Dynamika rozpowszechnienia Internetu w przekroju niedużych przedsiębiorstw oscylowało na początku 2002 roku od 17,07\% dla firm średnich do $49,05 \%$ w przypadku firm małych ${ }^{1}$. Zawarte powyżej dane statystyczne są uwarunkowane przez wiele czynników, mających swoje źródło w samej firmie, jak i poza nią. Ze względu na charakterystykę małych i średnich firm (m.in. relatywnie małe zasoby) szczególnie interesująco wyglądają uwarunkowania wewnętrzne.

Celem artykułu jest zaprezentowanie wyników badań empirycznych, prowadzonych w ramach projektu badawczego $\mathrm{nr}$ 1369/H02/2002/22 finansowanego przez Komitet Badań Naukowych, dotyczących takich kwestii, jak potencjał firm i wiedza członków organizacji względem e-biznesu, motywacja związana z wdrożeniem rozwiązań e-biznesowych czy też przejawy zastosowań technologii teleinformatycznych. Pod pojęciem e-biznesu autor rozumiał będzie wykorzystanie mediów elektronicznych, takich jak Internet, intranet, ekstranet do wymiany wartości (informacji, produktów, e-pieniądza). Analogicznie „polskie" nieduże firmy należy traktować jako te, które działają na terytorium Polski, abstrahując od źródeł ich kapitału.

\section{Metodologia badania}

W pierwszych trzech miesiącach 2002 roku przeprowadzono badania małych i średnich przedsiębiorstw mających swoją siedzibę w Polsce ${ }^{2}$. Zakres przedmiotowy obejmował zagadnienia stosowania rozwiązań e-biznesowych. Badania dotyczyły całego kraju, jednak z uwagi na dostępne środki badawcze

\footnotetext{
Autor jest doktorantem Akademii Ekonomicznej we Wroclawiu.

1 Obliczenia wlasne na podstawie: [Raport o stanie sektora matych $i$ Srednich przedsiębiorstw w Polsce w latach 2000-2001. Polska Agencja Rozwoju Przedsiẹbiorczości, Warszawa 2002, s. 267]; oraz [Raport o stanie sektora matych i srednich przedsiębiorstw w Polsce $w$ latach 1999-2000, Polska Agencja Rozwoju Przedsiębiorczości, Warszawa 2001, s. 313].

2 Klasyfikacji dokonano zgodnie z ustawą Prawo działalności gospodarczej, tj. wg kryterium wielkości zatrudnienia (tutaj wyodrębniono dodatkowo kategorię mikroprzedsiębiorstwa, firmy zatrudniającej do 9 pracowników) i uzyskiwanych przychodów netto.
} 
badania empiryczne koncentrowały się na Dolnym Śląsku. Dobór przedsiębiorstw do próby badawczej miał charakter celowy, oparty na kryteriach przedmiotowych. Aby podlegać badaniom firmy musiały spełniać dwa kryteria:

- należeć do kategorii polskich małych lub średnich przedsiębiorstw

- użytkować technologie internetową.

Ostatecznie zebrano odpowiedzi od 64 przedsiębiorstw. W związku z tym wnioski sformułowane na podstawie badań odnoszą się wyłącznie do przebadanych firm. Założeniem badania nie było jednak przeprowadzanie badań wyczerpujących, lecz analiza pozwalająca na zidentyfikowanie stanu e-biznesu w polskich małych i średnich przedsiębiorstwach widzianego pod kątem sformułowanych powyżej trzech obszarów problemowych.

Strukturę przebadanych przedsiębiorstw pod względem wielkości zatrudnienia oddaje wykres 1 .

Wykres 1. Struktura przebadanych przedsiębiorstw pod względem wielkosci zatrudnienia

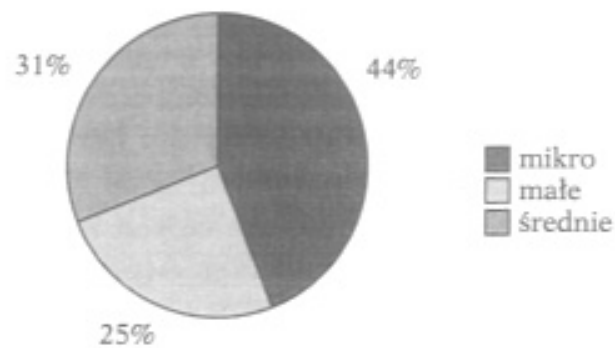

Źródło: opracowanie własne

W analizowanej próbie 28 firm zatrudnia do 9 pracowników, 16 podmiotów charakteryzuje się liczbą zatrudnionych z przedziału 10-49, zaś 20 przedsiębiorstw daje zatrudnienie od 50 do 249 osobom.

Ze względu na wolumen uzyskiwanych przychodów netto, 57 firm zanotowało obroty poniżej 25 milionów PLN netto. Reszta, tj. 7 przedsiębiorstw wypracowało przychody przekraczające tą wartość, ale nie przewyższające 145 milionów PLN.

Przedsiębiorstwa biorące udział w badaniu należą do różnych branż. Ich podstawowa klasyfikacja z punktu widzenia przedmiotu działalności przedstawia się następująco:

- przedsiębiorstwa produkcyjne - 26 firm $(41 \%)$

- przedsiębiorstwa usługowe - 25 firm (39\%)

- przedsiębiorstwa handlowe - 13 firm (20\%). 


\section{Potencjał firm i poziom umiejętności względem rozwiązań e-biznesowych}

O możliwości zastosowania rozwiązań e-biznesowych decydują w dużej mierze zasoby stojące do dyspozycji przedsiębiorstwa, jak również umiejętności ludzkie dotyczące tej sfery.

Potencjał przedsiębiorstwa niezbędny do wdrożenia i późniejszej eksploatacji technologii teleinformatycznych został na potrzeby badania określony poprzez poziom wydatków na rozwiązania e-biznesowe. Takie ujecie związane jest ze specyfiką sektora małych i średnich przedsiębiorstw, charakteryzujących się m.in. relatywnie małymi zasobami kapitałowymi.

Badanym przedsiębiorstwom zadano pytania dotyczące postrzegania poziomu nakładów związanych z e-biznesem zarówno na etapie implementacji, jak i eksploatacji. Dodatkowo, wydatki związane z wdrożeniem technologii internetowych odniesiono do uzyskanych w ciągu roku obrotów. Odpowiedzi potwierdzające wysoki poziom kosztów $w^{3}$ wskazują na niedostateczny potencjał niedużych firm, natomiast oceny przeciwne potwierdzają istnienie wystarczającej wielkości posiadanych zasobów kapitałowych.

Drugim czynnikiem, odgrywającym istotną rolę w prawidłowym wykorzystaniu e-biznesu, są określone umiejętności, jak również wiedza ludzi korzystających z rozwiązań e-biznesowych. W kwestionariuszu ankiety uwzględnione zostały kwestie posiadania przez respondentów wiedzy na temat poziomu wiedzy o gospodarczych możliwościach wykorzystania Internetu, jak również umiejętności obsługi oprogramowania internetowego. Opinie na powyższe tematy formułują generalnie przedsiębiorcy lub kadra menedżerska, ponieważ to oni właśnie stanowią większość respondentów. Jest to tyle istotne, iż od zaangażowania szefów firm zależy w dużym stopniu sukces we wdrażaniu rozwiązań e-biznesowych.

Jak zatem uczestniczące $\mathrm{w}$ badaniu małe i średnie przedsiębiorstwa oceniają swój potencjał w zakresie e-biznesu, a także wiedzę i umiejętności osób mających wpływ na podejmowanie decyzji w firmie? Zaczynając od percepcji kosztów odnoszących się implementacji technologii internetowych respondenci generalnie ocenili je jako niewysokie. Na 64 przedsiębiorstwa uczestniczące w badaniu, 43 określiło te koszty jako niewielkie, 3 jako średnie, zaś 13 jako duże. Jedynie w wypadku 5 firm nie potrafiono określić poniesionych wydatków na implementację technologii internetowej. Powyższe relacje w ujęciu graficznym oddaje wykres 2 .

3 Autor ze względów leksykalnych zamiennie używał bẹdzie bliskoznacznych określeń „koszt” i „wydatek", choć zdaje sobie sprawç z ich nieco odmiennego zakresu merytorycznego. 
Wykres 2. Okreslenie poziomu wydatk6w związanych z wdrożeniem technologii internetowych w relacji do rocznych obrotów

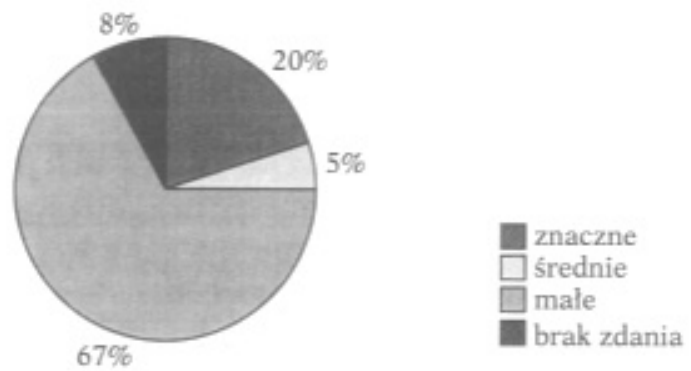

Źródło: opracowanie własne

Również bieżące koszty dotyczące wykorzystania Internetu w opinii respondentów nie są zbyt wysokie. W zdecydowanej większości respondenci oceniają koszty eksploatacji jako umiarkowane i małe (odpowiednio 28 i 27 przedsiębiorstw). Przeciwnego zdania jest 8 respondentów, przy czym co warte odnotowania, tylko w jednym przypadku koszty użytkowania przekraczają możliwości firmy. Również tylko w jednym wypadku powstał problem z określeniem wysokości nakładów. Sumarycznie opinie na temat bieżących kosztów korzystania z technologii internetowej zawiera wykres 3 .

Wykres 3. Okreslenie poziomu wydatków związanych z bieżącą eksploatacją technologii internetowej
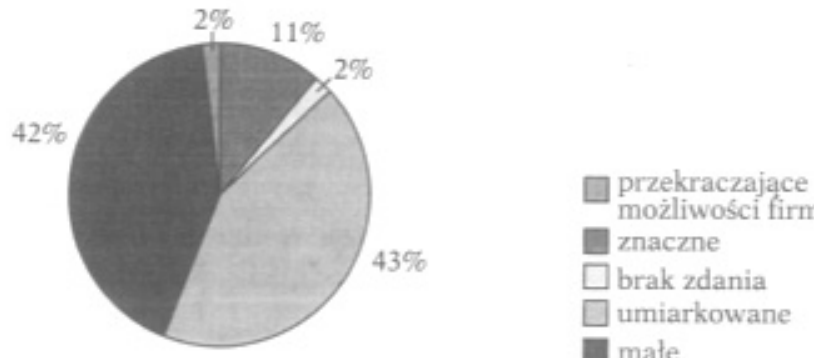

Źródło: opracowanie własne

Respondenci wysoko ocenili swoją wiedzę na temat gospodarczych możliwości wykorzystania Internetu. Świadczy o tym dobitnie z jednej strony brak odpowiedzi potwierdzających znikomą wiedzę na temat możliwości e-biznesu, zaś z drugiej koncentracja odpowiedzi w trzech najwyższych przedziałkach, oznaczających najwyższy stopień poinformowania o potencjale tkwiącym w technologiach internetowych. Szczegółowo zagadnienie to przedstawia wykres 4. Poziom wiedzy określony jest w skali od 1 do 10 , przy czym 1 oznacza zupełny brak wiedzy, zaś 10 pełną wiedzę o możliwościach wykorzystania technologii internetowych. 
Wykres 4. Poziom wiedzy na temat gospodarczych możliwosci wykorzystania Internetu

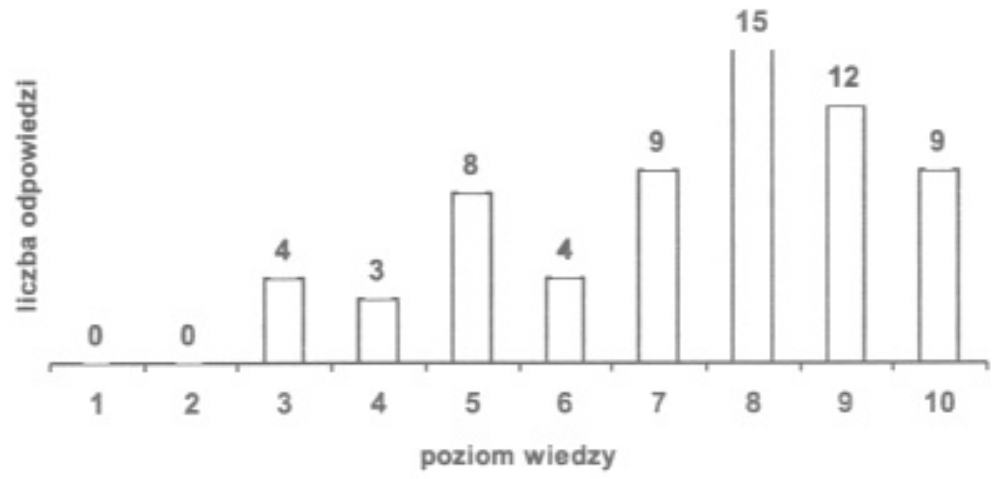

Zródło: opracowanie własne

Uwagi: skala dziesięciostopniowa, gdzie 1 zupełny brak wiedzy nt. gospodarczych moźliwości Internetu, zas 10 pełna wiedza na ten temat

Jak więc wskazuje powyższy wykres respondenci określający swoją znajomość możliwości e-biznesu jako co najmniej dobrą (zakres odpowiedzi: 7, 8, $9,10)$ stanowią $70,3 \%$; jako średnią (zakres odpowiedzi: $4,5,6)-23,5 \%$; jako słabą (zakres odpowiedzi: $1,2,3)-6,2 \% 4$. Podobnie sytuacja wygląda w odniesieniu do stopnia umiejętności posługiwania się oprogramowaniem związanym $\mathrm{z}$ internetem, jakkolwiek warto zaznaczyć, iż w tym przypadku rozkład odpowiedzi jest bardziej równomierny. Ilustruje to wykres 5 .

Wykres 5. Stopień umiejętnosci obslugi oprogramowania związanego z internetem

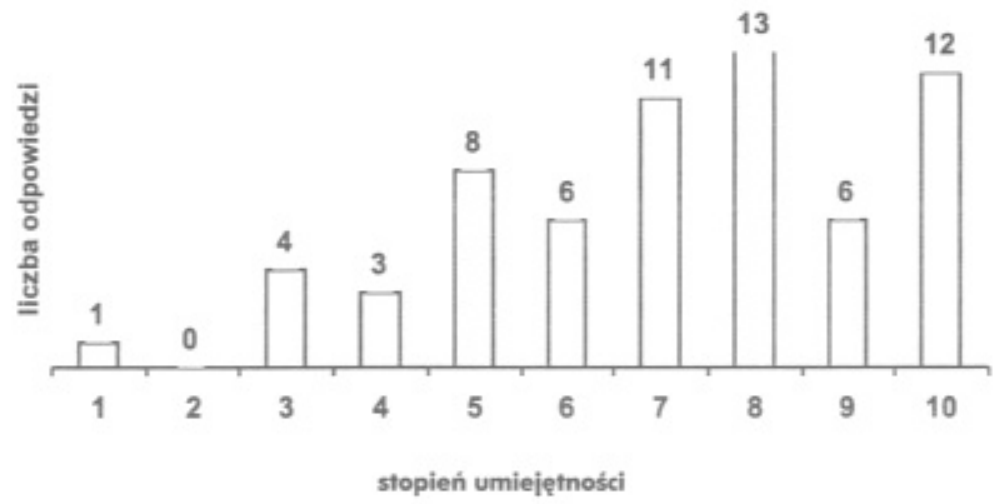

Źródło: opracowanie własne

Uwagi: skala dziesięciostopniowa, gdzie 1 zupełny brak umiejętności obsługi oprogramowania internetowego, zaś 10 pełna znajomość zasad korzystania z takiego oprogramowania

4 Niewątpliwie brak odpowiedzi w dwóch pierwszych przedziałkach wiąże się po części z faktem, iż badania dotyczyły firm stosujących technologie internetowe. 
Przyjmując poprzedni schemat określenia umiejętności oprogramowania związanego $\mathrm{z}$ internetem można stwierdzić, iż $65,6 \%$ respondentów posiada co najmniej dobrą jego znajomość (zakres odpowiedzi: 7, 8, 9, 10); 26,5\% średnią (zakres odpowiedzi 4, 5, 6); zaś 7,8\% słabą (zakres odpowiedzi 1, 2, 3).

$\mathrm{Na}$ zwiększenie stopnia umiejętności obsługi oprogramowania internetowego pozytywny wpływ ma długość okresu użytkowania danego rodzaju software'u. Dzieje się tak mimo częstego wprowadzania nowszych wersji tego samego programu, gdyż filozofia obsługi pozostaje w zasadzie stała. Ramy czasowe korzystania z poczty elektronicznej, Internetu, a także ewentualnie posiadanie przez firmy własnej strony www prezentuje tablica 1.

Tablica 1

Okres użytkowania danego rodzaju technologii internetowej w badanych firmach

\begin{tabular}{|l|c|c|c|c|c|}
\hline \multirow{2}{*}{$\begin{array}{c}\text { Rodzaj stosowanej } \\
\text { technologii internetowej }\end{array}$} & \multicolumn{4}{|c|}{ Okres uźytkowania: } & \multirow{2}{*}{ Razem } \\
\cline { 2 - 6 } & do roku & $\begin{array}{c}\text { ponad rok } \\
\text { do dwóch lat }\end{array}$ & $\begin{array}{c}\text { ponad dwa lata } \\
\text { do trzech lat }\end{array}$ & $\begin{array}{c}\text { ponad } \\
\text { trzy lata }\end{array}$ & \\
\hline Poczta elektroniczna & 11 & 15 & 16 & 20 & 62 \\
\hline Internet & 11 & 13 & 16 & 24 & 64 \\
\hline Strona www & 10 & 12 & 11 & 9 & 42 \\
\hline
\end{tabular}

Źródło: opracowanie własne

Pierwszą konstatacją narzucającą się po analizie powyższych informacji jest relatywnie duży odsetek firm korzystających z dostępu do Internetu i poczty elektronicznej ponad dwa lata. Oznaczać to może, iż technologie internetowe nie stanowią nowinki technologicznej i biznesmeni mieli czas na opanowanie ich stosowania. Przytoczone powyżej dane, jakkolwiek nie są reprezentatywne, wskazują też na fakt rozpoczęcia wykorzystania Internetu przed wybuchem fali entuzjazmu internetowego w roku 1999.

Spojrzenie przez pryzmat częstości stosowania w badanych firmach pokazuje, że praktycznie wszystkie korzystają z komunikacyjnych możliwości Internetu ( $97 \%$ próbki badawczej). Własną stroną może pochwalić się $66 \%$ przebadanych przedsiębiorstw.

Z powyższym, pozytywnym opisem własnych umiejętności, koresponduje chęć otrzymania zewnętrznego wsparcia informacyjno-szkoleniowego z zakresu rozwiązań e-biznesowych. Za takim wsparciem opowiada się 31 firm biorących udział w badaniu, czyli blisko połowa respondentów. Przeciwnego zdania są przedstawiciele 28 firm, a więc także z blisko połowy próby badawczej. 5 respondentów nie zajęło wyraźnego stanowiska w tej kwestii. $48 \%$ respondentów wyrażających chęć pogłębienia wiedzy lub/i umiejętności z zakresu technologii internetowej stanowi asumpt do wyciagniẹcia wniosku, iż mimo generalnego stanu zadowolenia $\mathrm{z}$ posiadanej wiedzy i umiejętności respondenci dostrzegają konieczność uaktualniania i poszerzania wiedzy. Jeżeli chodzi o preferencje firm odnośnie do formy wsparcia, to przedstawione one zostały w tablicy 2 . 
Preferowana forma wsparcia informacyjnego

\begin{tabular}{|c|l|c|}
\hline Lp. & \multicolumn{1}{|c|}{ Forma } & Liczba odpowiedzi \\
\hline 1 & Szkolenia & 16 \\
\hline 2 & Warsztaty & 16 \\
\hline 3 & Doradztwo ze strony dostawców sprzętu komputerowego ilub oprogramowania & 15 \\
\hline 4 & Publikacje w prasie biznesowej & 2 \\
\hline 5 & $\begin{array}{l}\text { Zatrudnienie w firmie informatyka, _który w każdej sytuacji może stuźyć } \\
\text { pomoca i rada" }\end{array}$ & 1 \\
\hline
\end{tabular}

Źródlo: opracowanie własne

Ankietowane przedsiębiorstwa polegają głównie na standardowych formach, takich jak szkolenia, warsztaty przed monitorem komputera czy też doradztwo ze strony dostawców sprzętu lub oprogramowania. Sporadycznie pojawiają się jednak także postulaty publikacji odpowiednich materiałów w prasie biznesowej, jak również chęć zatrudnienia we własnej firmie informatyka.

$\mathrm{Z}$ zamieszczonych informacji wylania się raczej pozytywny obraz wykwalifikowanych i zdających sobie sprawę z możliwości technologii teleinformatycznych polskich przedsiębiorców i kadry zarządzającej małym i średnim przedsiębiorstwem, jak również posiadania przez te firmy odpowiednich zasobów dla wdrożenia i korzystania z rozwiązań e-biznesowych. Jest to jednak obraz wykreowany przez respondentów i jako taki ma charakter subiektywny. Nie podważając znaczenia wyrażanych wyżej poglądów autor starał się zweryfikować w drodze wywiadu i obserwacji wypowiedzi respondentów. Według oceny autora w kilkunastu przypadkach można mówić o zbyt wysokim ocenieniu wiedzy na temat e-biznesu. Wiedza ta koncentrowała się na możliwościach wykorzystania Internetu do komunikacji, zdobywania informacji, ewentualnie celów promocyjno-reklamowych, nie obejmując wszakże bardziej zaawansowanych form wykorzystania. Z kolei w odniesieniu do umiejętności należy stwierdzić, że niektórzy respondenci posiadali bardziej specjalistyczne kwalifikacje. Potrafili przykładowo obsługiwać nie tylko standardowe oprogramowanie (programy pocztowe, przeglądarki internetowe, klient FTP \{ang. File Transfer Protocol\}, itp.), ale także posiadali znajomość języka HTML (ang. Hyper-Text Markup Language) czy też projektowania stron www.

\section{Motywacja implementacji e-biznesu}

Z wdrożeniem i stosowaniem rozwiązań e-biznesowych związane są określone motywacje. Motywacje te cechuje ogromna różnorodność, bowiem przedsiębiorcy widzą w e-biznesie możliwość zaspokojenia różnych potrzeb lub też rozwiązania (złagodzenia) różnorakich problemów, z jakimi borykają się ich firmy.

Jednym z głównych celów badania empirycznego było określenie przesłanek skłaniających biznesmenów do zainteresowania się technologiami interne- 
towymi. W kwestionariuszu ankiety znalazł się odpowiedni punkt, wyszczególniający motywy zastosowania Internetu w firmie. W ramach powyższego pytania autor przygotował zestaw odpowiedzi, które mogły być (i były) uzupełniane przez respondentów. W tablicy 3 przedstawiono motywacje leżące u podłoża wdrożenia i zastosowania Internetu w firmie. W tym miejscu warto od razu nadmienić, iż respondenci byli proszeni o zaznaczenie trzech najważniejszych ich zdaniem przesłanek zastosowania Internetu. W związku z tym liczba odpowiedzi znacząco przekracza liczebność próby.

Tablica 3

Motywy ležące u podstaw stosowania Internetu w badanych przedsiębiorstwach

\begin{tabular}{|c|c|c|c|c|c|}
\hline \multirow[b]{2}{*}{ Lp. } & \multirow[b]{2}{*}{ Motywy } & \multirow{2}{*}{\begin{tabular}{|c|} 
Względna \\
częstotliwośća) \\
w \%
\end{tabular}} & \multicolumn{3}{|c|}{ Motyw wymieniony na miejscu: } \\
\hline & & & pierwszym & drugim & trzecim \\
\hline 1 & Internet ułatwia i usprawnia funkcjonowanie firmy & 30,6 & 38 & 14 & 4 \\
\hline 2 & $\begin{array}{l}\text { Internet jest już albo będzie wkrótce niezbędny, } \\
\text { aby sprostać konkurencji }\end{array}$ & 22,4 & 11 & 15 & 15 \\
\hline 3 & $\begin{array}{l}\text { Konieczność elektronicznego przesyłania danych } \\
\text { do ZUS-u }\end{array}$ & 14,8 & 10 & 7 & 10 \\
\hline 4 & $\begin{array}{l}\text { Klienci negatywnie postrzegają firmę bez dostępu } \\
\text { do Internetu }\end{array}$ & 12,0 & 5 & 5 & 12 \\
\hline 5 & $\begin{array}{l}\text { Stosowanie Internetu wyrównuje szanse niedużych } \\
\text { firm i wielkich przedsiçbiorstw }\end{array}$ & 5,5 & 2 & 5 & 3 \\
\hline 6 & $\begin{array}{l}\text { Wdrożenie Internetu zapobiega zmnicjszeniu udziału } \\
\text { w rynku na rzecz firm już stosujacych Internet }\end{array}$ & 4,9 & 3 & 2 & 4 \\
\hline \multirow[t]{12}{*}{7} & Inne: & & & & \\
\hline & - dostep do informacji z otoczenia firmy & 2,7 & 3 & 2 & 0 \\
\hline & - cele marketingowe (np. reklama) & 1,6 & 1 & 2 & 0 \\
\hline & wymiana informacji & 1,1 & 1 & 1 & 0 \\
\hline & - bankowośc internetowa & 0,5 & 0 & 1 & 0 \\
\hline & - inne firmy stosuja Internet & 0,5 & 0 & 1 & 0 \\
\hline & $\begin{array}{l}\text { moźliwość zbierania zamówień przez } \\
24 \text { godzin na dobe }\end{array}$ & 0,5 & 0 & 1 & 0 \\
\hline & - pokazanie sie na rynku & 0,5 & 1 & 0 & 0 \\
\hline & dostarczanie Internetu innym firmom & 0,5 & 1 & 0 & 0 \\
\hline & - drialanie w skali calego kraju & 0,5 & 1 & 0 & 0 \\
\hline & - konieczność elektroniczunego obrotu danymi & 0,5 & 1 & 0 & 0 \\
\hline & $\begin{array}{l}\text { - Internet pojawil się jako uzupełnienie moźliwości } \\
\text { zakupionego do firmy komputera }\end{array}$ & 0,5 & 1 & 0 & 0 \\
\hline & Razem: & 100 & & & \\
\hline
\end{tabular}

Źródło: opracowanie własne

a) względna czẹstotliwość została obliczona w stosunku do całkowitej liczebności odpowiedzi

Zgodnie z przytoczonymi wyżej danymi przesłanki użytkowania technologii internetowej wiążą się z poprawą funkcjonowania firmy, nadzieją na teraźniejsze lub przyszłe wzmocnienie pozycji konkurencyjnej przedsiębiorstwa, narzuconej przez uwarunkowania prawne konieczności przekazu danych do ZUS-u. W dalszej kolejności pojawiają się motywy rynkowe, dotyczące bądź to wizerunku w oczach klientów, bądź też udziału w rynku. Z kolei w odnie- 
sieniu do wyrównania szans firm z sektora małych i średnich przedsiębiorstw w stosunku do firm dużych znaczenie Internetu oceniane jest jako marginalne źródło niwelowania dysproporcji dzielącej obie kategorie przedsiębiorstw. Świadczy o tym fakt, iż stwierdzenie: „Stosowanie Internetu wyrównuje szanse niedużych firm i wielkich przedsiębiorstw" poparło tylko 10 respondentów.

$\mathrm{Z}$ drugiej strony respondenci licznie wymieniali nieprzewidziane $\mathrm{w}$ formularzu ankiety motywy zastosowania technologii internetowej. Niektóre z nich odwołują się do gromadzenia informacji o otoczeniu firmy, inne dotyczą komunikacji, zagadnień marketingowych, naśladownictwa (inne firmy już to mają), motywów związanych z prestiżem (pokazanie się na rynku), itd. Nie sposób nie zauważyć, że wyspecyfikowane przez ankietowanych odpowiedzi wiążą się generalnie $\mathrm{z}$ korzyściami odczuwanymi dzięki wykorzystaniu Internetu. Tym samym wskazuje to na fakt, iź implementacja Internetu mogła być przedmiotem wcześniejszych rozważań, pewnego rodzaju kalkulacji oceniającej przydatność technologii internetowej w konkretnej sytuacji danego przedsiębiorstwa. Nie wyklucza to oczywiście sytuacji odwrotnej, czego przykładami są imitacja innych firm czy też pojawienie się Internetu niejako przy okazji zakupu sprzętu komputerowego.

Oprócz bezwzględnej liczebności odpowiedzi optujących za danym motywem wdrożenia Internetu w badanych firmach, interesującą kwestią jest także znaczenie poszczególnych przesłanek dla respondentów. Respondenci wymieniali bowiem trzy przyczyny, leżące u podstaw zastosowania Internetu, co z kolei stanowiło asumpt do uszeregowania odpowiedzi także według znaczenia dla ankietowanego. Takie ujęcie pozwoliło na pogłębienie analizy odnoszącej się do hierarchii motywów dotyczących rozwiązań e-biznesowych. Należy zaznaczyć, iż ankietowani mogli zaznaczyć więcej niż jeden motyw jako dla nich równorzędny, nie przyznać pierwszego (ewentualnie drugiego, trzeciego) miejsca w rankingu ważności, sformułować mniej niż 3 powody użytkowania Internetu.

Biorąc pod uwagę znaczenie poszczególnych motywów należy stwierdzić, iż podstawowy, najbardziej znaczący motyw w zasadzie pokrywa się z ogólną częstotliwością występowania. Tak więc najważniejsze przesłanki koncentrują się na funkcji usprawniającej działalność przedsiębiorstw w następstwie uży. cia Internetu, jego roli dla istniejącej i przyszłej konkurencyjności przedsiębiorstwa, jak również konieczności przesyłania danych do ZUS-u drogą elektroniczną dla części firm. Tym samym dominujące miejsce w hierarchii ważności przesłanek decydujących o wdrożeniu technologii teleinformatycznych zajmują czynniki nawiązujące w pośredni albo bezpośredni sposób do konkurencyjności przedsiębiorstwa.

Jako motywy skłaniające respondentów w drugiej kolejności do zastosowania Internetu najczęściej pojawiają się podobne przesłanki, jak w przypadku podstawowego motywu, z tą różnica, iż na czołową pozycję wysuwa się motyw w bezpośredni sposób odwołujący się do konkurencyjności przedsię̧biorstwa. Motyw Internetu jako niezbędnego czynnika konkurencyjności przedsiębiorstwa pozostaje też na czele przesłanek o trzeciorzędnym znaczeniu. 


\section{Przejawy wykorzystania technologii teleinformatycznych}

Z zagadnieniem motywacji implementacji technologii teleinformatycznych wiąże się kwestia faktycznie wykorzystywanych w danym przedsiębiorstwie możliwości Internetu. Motywy pojawienia się rozwiązań e-biznesowych w firmie stanowią bowiem powód pojawienia się tego typu technologii w firmie. Z czasem liczba zastosowań zmienia się - może się rozszerzyć, a niekiedy też zmniejszyć.

W analizowanej próbie firm technologie teleinformatyczne używane są generalnie do celów komunikacyjnych i informacyjnych, rzadziej zaś do celów transakcyjnych i dystrybucyjnych. Dane w tej materii przedstawia tablica 5.

Tablica 5

Zastosowania technologii internetowej $w$ badanych firmach

\begin{tabular}{|l|c|c|}
\hline \multicolumn{1}{|c|}{ Zastosowanie } & $\begin{array}{c}\text { Liczba } \\
\text { odpowiedzi }\end{array}$ & $\begin{array}{c}\text { Czestotliwośc } \\
\text { występowaniaa), w \% }\end{array}$ \\
\hline cele komunikacyjne - nadawanie i odbieranie e-maili & 62 & 96,9 \\
\hline zdobywanie informacji o kontrahentach i konkurentach & 45 & 70,3 \\
\hline promowanie/reklamowanie własnych produktów & 33 & 51,6 \\
\hline zwiększenie rozpoznania własnej marki & 27 & 42,2 \\
\hline $\begin{array}{l}\text { wspólny system wymiany informacji i zamówień z dostawcami } \\
\text { i odbiorcami }\end{array}$ & 23 & 35,9 \\
\hline zaopatrzenie, zamawianie materiałów, półproduktów, usług & 15 & 23,4 \\
\hline $\begin{array}{l}\text { wewnętrzny, komputerowy system informacyjny oparty } \\
\text { na technologiach internetowych }\end{array}$ & 15 & 23,4 \\
\hline $\begin{array}{l}\text { prowadzenie usług posprzedażnych (np. instrukcje obsługi } \\
\text { zamieszczone w Intemecie) }\end{array}$ & 13 & 20,3 \\
\hline sprzedaż wlasnych produktów poprzez Internet & 9 & 14,1 \\
\hline rekrutacja pracowników on-line & 2 & 3,1 \\
\hline dzierźawienie oprogramowania poprzez Internet (model ASP) & 0 & 0 \\
\hline $\begin{array}{l}\text { inne: } \\
\text {-przelewy bankowe (bankowośc internetowa) }\end{array}$ & 3 & 4,7 \\
\hline- archiwizacja danych dotyczaca komunikacji z dostawcami & 1 & 1,6 \\
\hline
\end{tabular}

Źródło: opracowanie wlasne

Uwagi: a) częstotliwość występowania oznacza stosunek liczby firm wykorzystujących dany rodzaj zastosowania do całkowitej liczebności badanej zbiorowości

Relatywnie najczęściej pojawiają się zastosowania komunikacyjne - w 96,7\% przypadków. Używanie technologii internetowej do komunikacji przerosło nawet zastosowanie związane $\mathrm{z}$ gromadzeniem informacji $\mathrm{z}$ mikro- $\mathrm{i}$ makrootoczenia.

Promowanie i/lub reklamowanie własnych produktów, jak również zwiększenie rozpoznania własnej marki stanowiło kolejne pod względem popularności zastosowanie technologii teleinformatycznych. Powyższe dwa rodzaje czynności związane są z posiadaniem własnej strony www, na której zawartość prezentuje firmę i produkty, tym samym przyczyniając się do wzrostu 
rozpoznania wśród internautów własnej marki. Potwierdzeniem takiego stanu rzeczy jest podobna liczba firm posiadających strony internetowe ( $w$ badanej próbie znalazły się 42 takie firmy). Jednak obserwacja własna prowadzona przez autora wskazuje na fakt, iż firmowe strony nie zawsze spełniają cele marketingowe. W kilku przypadkach na stronach www zawarto jedynie podstawowe dane teleadresowe i ogólne dane o firmie, nie umieszczając bardziej „wyrafinowanych” informacji. Tym samym trudno tu mówić o promowaniu firmy czy też jej produktów. Inne mankamenty dotyczące stron www związane były z niewysokim poziomem funkcjonalności stron, złym opisem znaczników odpowiadających za skuteczność wyszukiwania w popularnych wyszukiwarkach internetowych, niedobranym wystrojem graficznym. W jednym przypadku w ogóle nie można było wejść na stronę firmową. Z drugiej strony co najmniej klika firm może pochwalić się dopracowaną pod względem merytorycznym i graficznym witryną internetową, a w zasadzie wieloma hierarchicznie ułożonymi stronami i podstronami, prezentującymi nie tylko firmę i jej produkty, ale też na przykład stany magazynowe.

Wspólny system wymiany informacji i zamówień z dostawcami i odbiorcami znalazł się na kolejnym, piątym pod względem popularności stosowania miejscu. Od razu należy zaznaczyć, iż respondenci stosują w większym stopniu wymianę informacji via e-mail, niż wymianę danych poprzez wspólne interfejsy, np. w standardzie Web - EDI. Możliwość zamawiania przyjmowała formę wysyłania listu elektronicznego z prośbą o przysłanie określonej partii dostawy. Tym niemniej pozwala to na relatywnie szybkie interaktywne dopasowanie wzajemnych wymagań.

Analogicznie rzecz się ma z zaopatrzeniem on-line. Generalnie pod tym hasłem chodzi o zamawianie materiałów, półproduktów, usług z wykorzystaniem strony www i poczty elektronicznej. Autor nie stwierdził występowania bardziej zaawansowanych systemów wymiany danych, aczkolwiek trzeba przyznać, że w większości firm stosowane rozwiązania są wystarczające z punktu widzenia ich potrzeb i możliwości finansowych.

15 firm wykorzystuje technologię internetową jako wewnętrzny system informacyjny. Z powyższym faktem koresponduje deklarowanie przez 49 firm, a więc ponad $3 / 4$ badanych, wewnętrznej sieci komputerowej. Oznaczać to może, iż logika obsługi oprogramowania internetowego jest dla respondentów na tyle przejrzysta i przyjazna, iż warto ją zastosować także w pozostałych systemach komputerowych.

Prowadzenie usług posprzedażnych deklarowane jest przez 20,3\% badanych przedsiębiorstw. Najpopularniejszym przykładem z tego zakresu są instrukcje obsługi zamieszczone na stronie www. Jednak obserwacje przeprowadzone przez autora na stronach www nie potwierdzają takiego poziomu wykorzystania Internetu w tym zakresie. Być może reszta dokonywana jest za pomocą poczty elektronicznej.

Ostatnim relatywnie często spotykanym wśród badanych firm zastosowaniem technologii internetowej jest sprzedaż własnych produktów. Transakcyjne możliwości sieci wykorzystuje $9 \mathrm{z} 64$ przebadanych firm, co stanowi oko- 
ło $14 \%$. Wielkość powyższa potwierdza, że w momencie przeprowadzania badań ankietowane przedsiębiorstwa w dużo większej mierze korzystały z komunikacyjnych i informacyjnych niż transakcyjnych możliwości Internetu.

Pozostałe zastosowania charakteryzują się stosunkowo małym oddźwiękiem wśród respondentów. Warto zwrócić uwagę, iż dosłownie żadne przedsiębiorstwo nie korzysta z możliwości dzierżawienia oprogramowania poprzez Internet. Przyczynę takiego stanu rzeczy upatrywać można we względnej nowości tego typu rozwiązania, jak również awersji części przedstawicieli small businessu wobec płacenia za legalne oprogramowanie.

Obok uchwycenia bieżącego stanu wykorzystania technologii teleinformatycznej badania dotyczyły także określenia planów badanych przedsiębiorstw odnoszących się do sfery zastosowania Internetu. Odpowiedzi respondentów, w przekroju okresu planowania, zawarte są w tablicy 6 .

Tablica 6

Plany zastosowania technologii internetowej w horyzoncie czasowym jednorocznymi i trzyletnim, dane przedstawione wedlug liczby odpowiedzi

\begin{tabular}{|c|c|c|}
\hline \multirow[b]{2}{*}{ el } & \multicolumn{2}{|c|}{ Horyzont planowania: } \\
\hline & $1 \mathrm{rok}$ & 3 lata \\
\hline założyć strone internetową informująca o produktach ilub firmie & 13 & 4 \\
\hline załoźyć stronę internetową reklamująca i promujaca produkty & 9 & 3 \\
\hline sprzedawać poprzez Internet & 8 & 14 \\
\hline składać zamówienia poprzez Internet & 17 & 10 \\
\hline dzierżawić oprogramowanic poprzez Internet (model ASP) & 2 & 2 \\
\hline $\begin{array}{l}\text { Inne: } \\
\text { uzyskać szerokopasmowy dostep do Internetu platny ryczahtowo }\end{array}$ & 2 & 0 \\
\hline zakonczyć projektowanie strony internetowej & 1 & 0 \\
\hline przyjmować zamówienia od klientôw & 1 & 0 \\
\hline uzyskać dostep do Internetu dla pracowników w terenie & 1 & 0 \\
\hline $\begin{array}{l}\text { promocja wlasnej strony w kolejnych pasazach handlowych duzych portali } \\
\text { oraz katalogach stron, wyszukiwarkach, itp. }\end{array}$ & 1 & 0 \\
\hline uzyskać zdalny dostep (przez laptopy, palmtopy, itd) & 1 & 0 \\
\hline $\begin{array}{l}\text { certyfikacja strategicznych klientów (nadanie uprawnień do automatycznego } \\
\text { zamawiania) }\end{array}$ & 1 & 0 \\
\hline zamieszczanie na firmowej stronie www biezacych stanów magazynowych & 1 & $\underline{0}$ \\
\hline wykorzystać Internet do szkolenia przedsiebiorcy i pracowników & 1 & 0 \\
\hline zaistnienic na gieldzie internetowej w celu sprzedazy własnych wyrobów & 0 & 1 \\
\hline polaczyć jednym systemem wsystkie biura handlowe & 0 & 1 \\
\hline stale udoskonalać promocje firmy & 0 & 1 \\
\hline
\end{tabular}

Źródło: opracowanie własne

Udzielone odpowiedzi można pogrupować w trzech kategoriach.

Do pierwszej z nich zaliczyć należy przedsiębiorstwa, w których plany mają w miarę standardowy charakter, a wiẹc dotyczą założenia własnej witryny internetowej, zamawiania lub sprzedaży poprzez Internet. Tego typu plany są najbardziej liczne, zaś w ujęciu przedmiotowym koncentrują się na planach składania zamówień, e-commerce, założeniu strony internetowej informującej o firmie i/lub produktach. Plany odnoszące się do zamawiania mają charak- 
ter zdecydowanie krótkoterminowy. Odwrotnie się ma kwestia sprzedaży on-line. Jeżeli badane firmy planują w tym zakresie, to generalnie w dłuższym horyzoncie czasowym. W przypadku chęci założenia własnej witryny internetowej plany dotyczą najbliższego roku. Wartym odnotowania jest też fakt, iż cztery przedsiębiorstwa zamierzają skorzystać z modelu ASP.

Druga grupę stanowią firmy, które nie wyspecyfikowały w ogóle swoich planów w zakresie technologii teleinformatycznych. 15 firm biorących udział w badaniu nie określiło w najmniejszym stopniu swoich zamiarów odnośnie Internetu. $\mathrm{Z}$ dociekań jakie prowadził autor wynika, że taka postawa jest pochodną dwóch typów stanowisk:

a) nie ma w ogóle dalszych planów co do Internetu, gdyż to co już funkcjonuje spełniło oczekiwania respondentów lub też Internet pojawił się incydentalnie w związku z koniecznością narzuconą przez ZUS;

b) respondenci nie chcieli zdradzić swoich zamierzeń względem tej sfery.

Trzecia grupa firm dodała do listy standardowych planów swoje własne, specyficzne zamierzenia. $\mathrm{Z}$ poznawczego punktu widzenia może cieszyć fakt, iż grupa ta jest dość liczna. Plany te dotyczyły szerokiego zakresu spraw, od najbardziej „przyziemnych”, technicznych kwestii dotyczących zwiększenia przepustowości łączy, aż po nadanie specjalnych uprawnień strategicznym klientom w celu zaawansowanego systemu zamawiania.

W przekroju horyzontu okresu planowania w badanych przedsiębiorstwach przeważa planowanie krótkoterminowe do jednego roku. Łącznie tej kategorii planowania dotyczyły 59 zapowiedzi, podczas gdy planowanie o wydłużonym horyzoncie - 36. Może to świadczyć o rzeczywistej chęci wdrożenia kolejnych rozwiązań e-biznesowych, gdyż realizacja celów krótkoterminowych jest bardziej prawdopodobna.

\section{Podsumowanie}

Wyniki badań skłaniają do następujących wniosków.

Zarówno potencjał badanych przedsiębiorstw, jak i umiejętności oraz wiedza na temat e-biznesu respondentów były wystarczające, aby wdrożyć i eksploatować technologie teleinformatyczne. Badane przedsię̧biorstwa charakteryzowały się w większości odpowiednią kadrą, potrafiącą wykorzystać potencjał e-biznesu, oczywiście z przytoczonymi wcześniej zastrzeżeniami. Zdecydowana większość badanych firm posiada wystarczające zasoby, aby móc korzystać z rozwiązań e-biznesowych.

Brak wymienienia wśród motywów Internetu jako środka prowadzącego do obniżenia kosztów funkcjonowania przedsiębiorstwa. Żaden z respondentów nie wskazał na oszczẹdność kosztów jako motywację do zastosowania Internetu. Oznaczać to może postrzeganie technologii internetowej w fazie zamiaru zaistnienia w wirtualnym wymiarze jako technologii kosztownej, które to spojrzenie zmienia się jednak pod wpływem wdrożenia i późniejszego stosowania w przekonanie przeciwne. Widać tu rolę dla publicznych środków przekazu w kierunku zwiększania wiedzy na temat rozwiązań e-biznesowych. 
Badane przedsiębiorstwa wykorzystują te rodzaje zastosowań technologii teleinformatycznych, które lokują się w początkowych fazach rozpowszechnienia e-biznesu. Powszechnie wykorzystywane są następujące rodzaje zastosowań: poczta elektroniczna, gromadzenie informacji via Internet, promowanie produktów i własnej firmy. Dużo rzadziej badane przedsiębiorstwa korzystają z zamówień on-line, e-commerce czy rekrutacji pracowników tą drogą. Jest symptomatyczne, że żadna firma nie dzierżawi oprogramowania poprzez Internet w modelu ASP. Świadczy to o fakcie, iż bardziej zaawansowane i kompleksowe rozwiązania są dopiero przed ankietowanymi przedsiębiorstwami.

Zwraca uwagę fakt, iż ponad $20 \%$ badanych przedsiębiorstw nie formułuje żadnych planów dotyczących technologii teleinformatycznych. Jednakże uwzględniając takie czynniki, jak właściwe dla małych i średnich przedsiębiorstw słabości planowania, niechęć udzielania odpowiedzi w tej kwestii, wykorzystanie w mniemaniu części badanych wszystkich interesujących ich moźliwości technologii internetowej, poziom ten należy uznać za relatywnie niski, co wskazuje, iż rozwiązania e-biznesowe cieszą się prospektywnym zainteresowaniem badanych.

\section{Bibliografia}

Raport o stanie sektora malych $i$ średnich przedsiębiorstw w Polsce w latach 2000-2001, [2002],Polska Agencja Rozwoju Przedsiębiorczości, Warszawa, s. 267

Raport o stanie sektora matych i srednich przedsiębiorstw w Polsce w latach 1999-2000, [2001], Polska Agencja Rozwoju Przedsiębiorczości, Warszawa, s. 313. 